\title{
Silicic acid regeneration from estuarine sediment $\operatorname{cores}^{*}$
}

\author{
Susan S. Yamada and Christopher F. D'Elia** \\ Chesapeake Biological Laboratory, P.O. Box 38, Solomons, Maryland 20688, USA
}

\begin{abstract}
The release of silicic acid from sediments is known to play an important role in determining the silicic acid concentration in the water columns of estuaries, but factors controlling the rate of release are poorly understood. Silicic acid efflux from sandy Chesapeake Bay sediment cores that were maintained in the dark was strongly dependent on biogenic silica deposition, temperature and salinity, but was independent of oxygen concentration in the overlying water. Silica dissolution and release from the cores accelerated rapidly with temperature above $15^{\circ} \mathrm{C}$. The release rate also accelerated very rapidly with salinity increase between $10 \%$ and $20 \%$, but was less dependent on change in salinity in the low and high ranges. These findings help account for observed late summer maxima in water-column silicic acid concentrations in mesohaline regions of Chesapeake Bay.
\end{abstract}

\section{INTRODUCTION}

Silicic acid $\left(\mathrm{H}_{4} \mathrm{SiO}_{4}\right)$ regeneration from biogenic silica appears to be a major pathway in the estuarine silicon cycle. In some estuaries, at least during summer, regenerated silicic acid inputs exceed allochthonous inputs to the water column (Wilke and Dayal, 1982; D'Elia et al., 1983; Helder et al., 1983). Regeneration of silicic acid from particulate silica suspended in the water column has been shown by itself to be inadequate to account for the observed summer increases in silicic acid concentrations (van Bennekom et al., 1974). Such increases must also result from regeneration of silicic acid from recently deposited biogenic silica in diatomaceous debris in the sediments (van Bennekom et al., 1974; Pilson et al., 1980). Silicic acid flux from the sediments into the water column has been measured in Long Island Sound (Aller and Benninger, 1981), in Narragansett Bay (Nixon, 1981), and in Chesapeake Bay (D'Elia et al., 1983). The sediments in each location constitute a significant source of silicic acid to the water column, with sediment effluxes ranging from 2 to 7.5 times the principal allochthonous input source on an annual basis (Table 1).

To understand the silicon cycle of estuaries, we

\footnotetext{
- Contribution No. 1526, Center for Environmental and Estuarine Studies, University of Maryland

- Addressee for reprint requests
}

clearly need to understand the factors affecting the rate of regeneration of silicic acid from silica. This rate depends on the supply and surface area of substrate (i.e. mineral and biogenic silica) available, the dissolution rates of the silica forms present, and the solubility of silicic acid. Dissolution of biogenic silica is of particular interest, since dissolution of this form of silica is quite rapid relative to that of mineral crystalline forms (e.g. Hurd, 1972), which for ecological purposes can be considered inert. Most previously published studies have not examined the dissolution of biogenic silica under estuarine conditions. Although the effects of environmentally important factors on the solubility of silicic acid have been well studied (Greenberg and Price, 1957; Hurd and Theyer, 1975; Kamatani and Riley, 1979), silicic acid is likely to be found at concentrations considerably below saturation in the water columns and surface sediments of most estuaries. Accordingly, factors affecting the dissolution rate of biogenic silica and the amount of substrate available are undoubtedly of greater importance in determining the rate of regeneration of silicic acid in estuaries.

The dissolution rate of biogenic silica varies considerably with chemical composition and temperature of the solution (Werner, 1977). All of the major salts in sea water strongly catalyze silica dissolution, so that the dissolution rate of silica in sea water is several orders of magnitude greater than in distilled water (Kato and Kitano, 1968; Kamatani, 1971). However, the relation 
Table 1. Comparison of silicic acid recycled from benthic sources to principal allochthonous silicic acid sources in several estuaries

\begin{tabular}{|c|c|c|c|c|}
\hline & Estuary & $\begin{array}{l}\text { Allochthonus } \mathrm{Si} \\
\text { moles } \mathrm{m}^{-2} \mathrm{yr}^{-1}\end{array}$ & $\begin{array}{l}\text { Recycled Si } \\
\text { moles } \mathrm{m}^{-2} \mathrm{yr}^{-1}\end{array}$ & Ratio \\
\hline & $\begin{array}{l}\text { Narragansett Bay } \\
\text { Nixon (1981) }\end{array}$ & $0.325^{\mathrm{a}}$ & $2.42^{b}$ & 7.5 \\
\hline & $\begin{array}{l}\text { Long Island Sound } \\
\text { Aller and Benninger (1981) }\end{array}$ & $0.657^{c}$ & $1.28^{\mathrm{d}}$ & 1.9 \\
\hline & $\begin{array}{l}\text { Chesapeake Bay } \\
\text { D'Elia et al. }(1983)^{c}\end{array}$ & $0.76^{\mathrm{e}}$ & $1.96-4.1^{\prime}$ & $2.5-5.4$ \\
\hline & \multicolumn{4}{|c|}{$\begin{array}{l}\text { Estimated from volume of water advected into the main basin of Long Island Sound multiplied by mean silica content of } \\
\text { that water } \\
\text { denthic fluxes of sediment cores were measured, with yearly benthic fluxes extrapolated from the temperature relation for } \\
\text { summer fluxes }\end{array}$} \\
\hline
\end{tabular}

between silicic acid regeneration and salinity has not been examined in detail. The dissolution rate also increases with temperature, both in Tris buffer solutions (Lewin, 1961) and in sea water (Lawson et al., 1978).

The present study evaluates factors affecting the rate of silicic acid regeneration in estuarine sediments. We used sediment cores to reproduce as closely as possible the conditions under which silica dissolution in estuarine sediments occurs. These cores were exposed to a range of temperatures, salinities, and biogenic silica input rates to determine the effects of these factors on the benthic release of silicic acid to the estuarine water column.

\section{MATERIALS AND METHODS}

Cores were taken using a 3.5 or $5.7 \mathrm{~cm}$ diameter Plexiglas tube from sandy sediments at depths of 1 to $3 \mathrm{~m}$ in the vicinity of the Chesapeake Biological Laboratory pier near the mouth of the Patuxent River on Chesapeake Bay during late summer. During this period, salinities were between 11 and $14 \%$ and water temperatures were between 25 and $30^{\circ} \mathrm{C}$. Sediments in the area sampled were composed of $98 \%$ sand with the remainder being silt and clay (J. Boynton, pers. comm.).

Cores were preincubated for from 7 to $21 \mathrm{~d}$ in the dark with overlying water at the same salinities and temperatures as the subsequent experiments, after which a suspension of diatoms, serving as a source of deposited biogenic silica was layered over the surface of the cores. The diatom used, Thalassiosira pseudonana, Clone $3 \mathrm{H}$, is a small ( $3 \mu \mathrm{m}$ diameter) centric, estuarine diatom that is an important component of the Chesapeake Bay phytoplankton in all but the winter months (van Valkenberg et al., 1978). The alga was cultured in sterile bay water enriched with $\mathrm{f} / 4$ nutrient supplement (Guillard and Ryther, 1962) with $0.44 \mathrm{mM}$ silicic acid. Batch cultures of $T$. pseudonana were allowed to settle in the dark for $4 \mathrm{~d}$ to make a concentrated suspension. The diatom suspension was not tested for viability, but since planktonic diatoms do not survive well in the dark (Lewin, 1961), we assume that they were moribund when added to the cores. Biogenic silica was added to the cores in an amount $(60$ mmol $\mathrm{m}^{-2}$ ) equivalent to several days accumulation of the normal summer deposition to Chesapeake Bay sediments (D'Elia et al., 1983). The cores were then incubated in the dark, and silicic acid concentrations in the water over the cores were determined periodically according to Technicon method 188-72WB1 using a Scientific Instruments Continuous Flow Analyzer (Model CFA 200). Particulate biogenic silica was determined using a slight modification of Paasche's (1973) sodium hydroxide digestion method (D. Nelson, pers. comm.).

\section{RESULTS}

The flux of silicic acid from freshly collected sediment cores was in some cases considerable, but dissolvable silica in the cores was quickly exhausted. For example, in one set of cores with a mean initial release rate of $1.6 \mathrm{mmol} \mathrm{H}_{4} \mathrm{SiO}_{4} \mathrm{~m}^{-1} \mathrm{~d}^{-1}$, the rate declined to $0.13 \mathrm{mmol} \mathrm{H}_{4} \mathrm{SiO}_{4} \mathrm{~m}^{-1} \mathrm{~d}^{-1}$ after $1 \mathrm{wk}$ of incubation at $22^{\circ} \mathrm{C}$ (not shown). The application of a layer of moribund planktonic diatoms to the core surface resulted in a steady and more prolonged flux of $\mathrm{H}_{4} \mathrm{SiO}_{4}$ 
from the cores. The release rate from cores at $22^{\circ} \mathrm{C}$ was independent of the oxygen concentration of overlying water but was directly proportional to the amount of biogenic silica applied to the cores (Fig. 1). These observations suggest that silicic acid regeneration depends more strongly on recent deposition rates of biogenic silica to surface sediments than on silica dissolution rates in older, deeper sediments. Unfortunately, we do not have $\mathrm{H}_{4} \mathrm{SiO}_{4}$ profiles of sediment interstitial porewaters from which we can estimate dissolution rates in the deep sediments.

When cores onto which biogenic silica had been freshly deposited were incubated at various temperatures, effluxes of silicic acid into the water over the cores were low at temperatures below $15^{\circ} \mathrm{C}$, but increased rapidly and exponentially above $15^{\circ} \mathrm{C}$ (Fig. 2). We were unable to find a theoretically valid mathematical model to represent the relationship.

Salinity had a marked effect on silicic acid release from the sediment cores (Fig. 3). This release did not vary in direct proportion to the salinity, but instead was low at salinities below $10 \%$, accelerated rapidly with salinity in the 10 to $20 \%$ range, and was high and relatively constant above $20 \%$ (Fig. 3). There was a 50 fold increase in the efflux from the lowest to the highest salinities. The initial $\mathrm{pH}$ 's of the artificial sea water

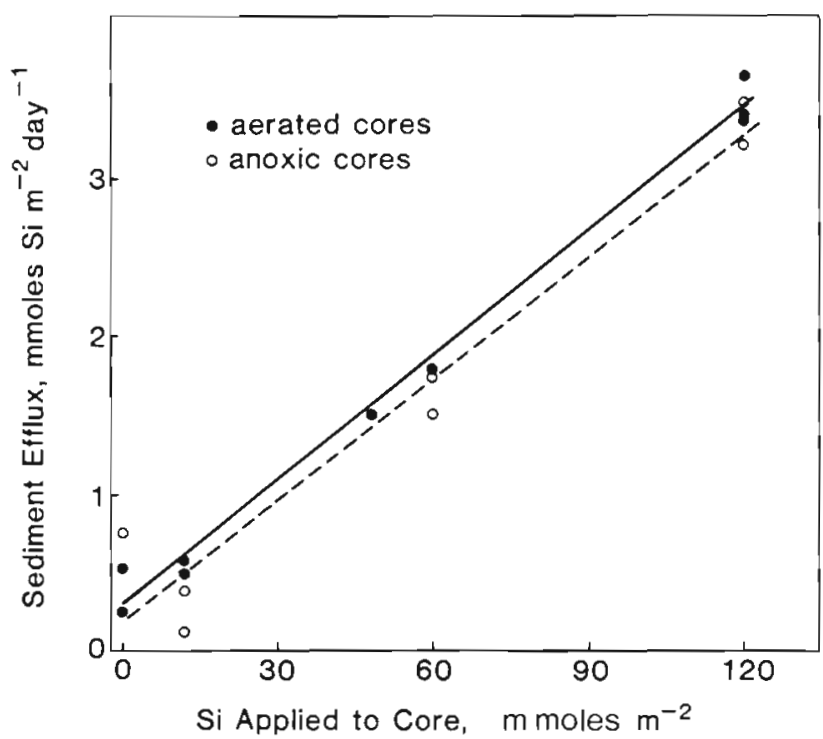

Fig. 1. Sediment efflux of silicic acid at $22^{\circ} \mathrm{C}$ as a function of the amount of biogenic silica added to the cores, under both anoxic and aerated conditions. The water over the aerated cores was bubbled constantly with filtered, humidified air to maintain the top layer of the sediment in oxidized condition. Anoxic conditions were created by sealing the Plexiglas tube ends. Sediments and the water above were black with released sulfide during the experiment, Eh values were in the -200 to -300 range, and dissolved oxygen levels were less than $1 \mathrm{mg} \mathrm{ml}^{-1}$, the lower limit of detection for the oxygen meter used. Equations for the linear regressions were: aerated cores, $y=0.0262 \times 0.295$; anoxic cores, $y=0.0254 x+0.199$

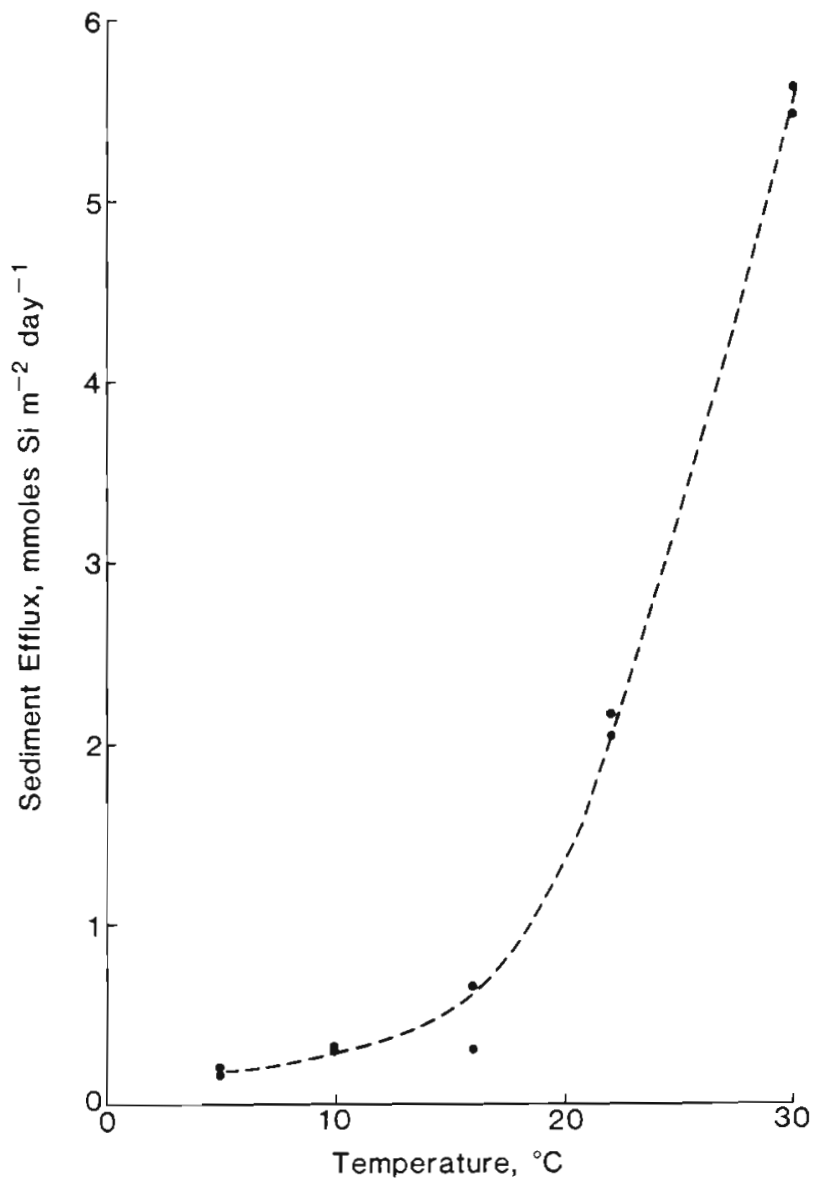

Fig. 2. Rate of efflux of silicic acid from the cores vs. temperature at local salinity $(14.4 \%)$. Rates of efflux were computed only for periods of time when silicic acid concentrations in the water above the cores increased with time at a linear rate and silica substrate available for dissolution was not exhausted

at all salinities were all between 7.70 and 7.80 , except for at $5 \%$, which was $\mathrm{pH} 7.55$. The pH probably fell further during the course of the experiment, but the results of Matisoff et al. (1975), who measured the $\mathrm{pH}$ of interstitial water in a low salinity region of Chesapeake Bay, suggest that the $\mathrm{pH}$ probably never fell lower than $\mathrm{pH} 7.2$ to 7.4 in either the water column or the sediment cores of our experiment. According to data on the change in the value of $\mathrm{k}_{2}$ with $\mathrm{pH}$ from Hurd (1973), a drop in $\mathrm{pH}$ of this magnitude would decrease the dissolution rate of silica by $30 \%$, much less than the salinity effect we observed.

\section{DISCUSSION}

Our results indicate that the deposition rate of biogenic material to the sediment surface, the salinity of the overlying water and the ambient temperature all have substantial effects on the efflux of silicic acid 


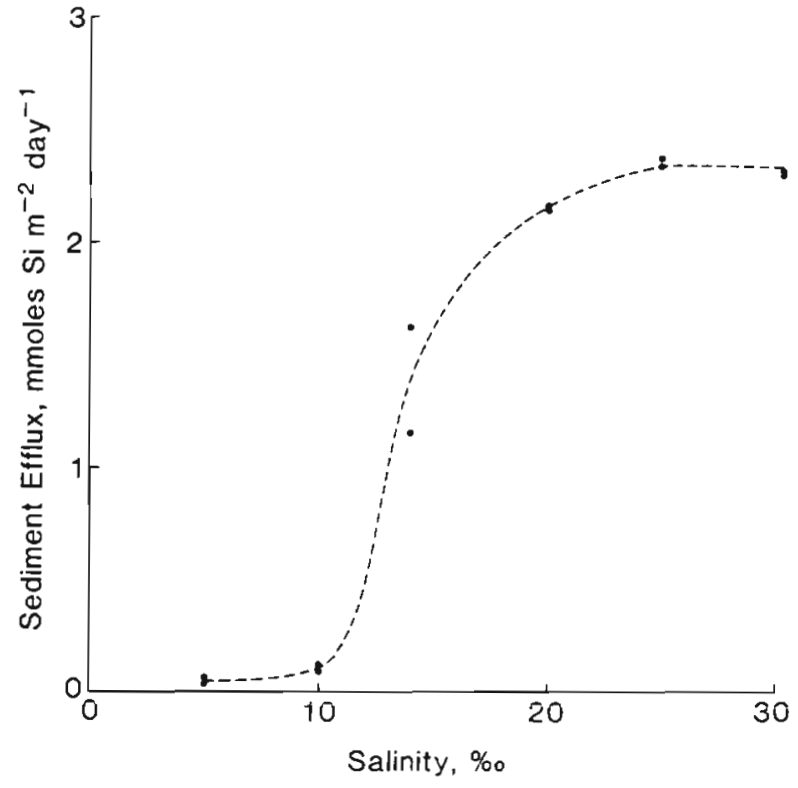

Fig. 3. Rates of efflux of silicic acid at $22{ }^{\circ} \mathrm{C}$ from duplicate cores vs. salinity. Artificial sea water (Lyman and Fleming 1940) was diluted with distilled water to achieve salinities between 5 and $30 \%$

from estuarine sediments. While we did not measure factors affecting silicic acid regeneration from particulate material suspended in estuarine waters, we assume that silicic acid regeneration in the water column is similarly affected.

Under certain conditions, i.e. at higher temperatures and salinities, biogenic silica deposited on the sediment surface appears to recycle very quickly, as D'Elia et al. (1983) assumed in their calculations in which they related benthic silica release to a minimum estimate of diatom productivity in the overlying water column. In the present study, we found that silicic acid regeneration from the cores occurred in direct proportion to the amount of biogenic silica applied (Fig. 1) and that the rate of silicic acid regeneration from freshly collected cores declined rapidly with time after collection. Accordingly, realistic measurements of natural rates of silicic acid regeneration appear to be reliably obtainable only with freshly collected cores. Our observations also suggest that the greatest contributor to the benthic flux of silicic acid, at least during the warmer months and at higher salinities, is that material deposited on the sediment surface and not that buried beneath the sediment surface.

Fluxes of silicic acid from cores incubated at various temperatures increased rapidly with temperature. The most complete set of comparable published data on the dissolution of whole diatoms that we could find was that of Lawson et al. (1978), in which natural phytoplankton assemblages were dissolved in sea water. When we replotted Lawson et al.'s data in a form similar to ours (Fig. 4), we found that the increase in the dissolution rate of biogenic silica with temperature is very similar in the 2 data sets (Fig. 2 and 4). In the present study and also in the work of Lawson et al., the dissolution rate of silica increases exponentially in the temperature range typical of Chesapeake Bay summer waters. Our data did not prove amenable to modeling using standard $Q_{10}$ equations. However, the data of Lawson et al. are more amenable to mathematical treatment and yield a $Q_{10}$ of approximately 2.5 in the temperature range from 7 to $28{ }^{\circ} \mathrm{C}$.

Anoxic conditions occur frequently in some estuaries like Chesapeake Bay during the summer (Taft et al., 1980), and could possibly affect silica dissolution. Metal cations such as aluminum or iron can sorb to particles of silica and sharply reduce their dissolution rate (Lewin, 1961). Lewin has suggested that under reducing conditions, the iron associated with silica particles may be removed by sulfide to form ferrous sulfide (FeS). Freed of its protective coating of iron, the silica might then dissolve more rapidly. In this study, aerated and anoxic cores showed no significant differences in the rate of efflux of silicic acid (Fig. 1). Therefore, association with the reducing sandy sediments used in this study seems not to affect the dissolution of silica. However, iron association with other types of reducing sediments may well have a greater effect on

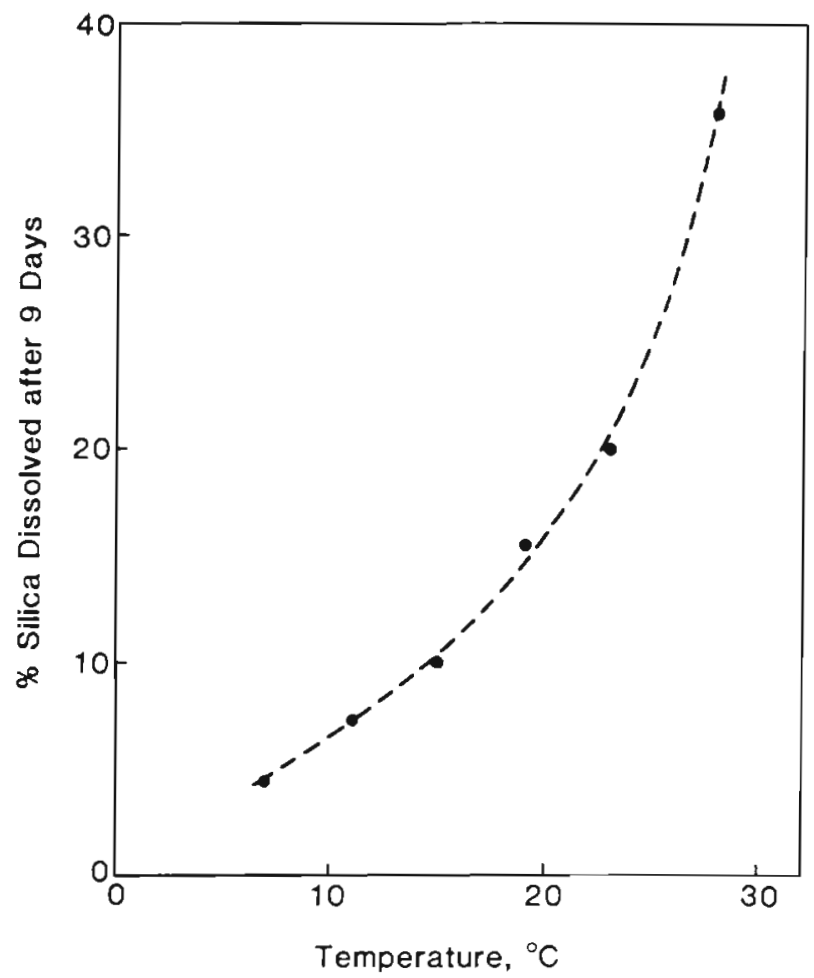

Fig. 4. Dissolution rate versus temperature for the data of Lawson et al. (1978) in their Fig. 1 
silica dissolution than it did in these sandy cores. This should be investigated further.

The pronounced effects of salinity and temperature on the dissolution rate of biogenic silica have implications regarding the spatial distribution of silicic acid dissolution and regeneration rates in an estuary such as Chesapeake Bay. In low-salinity regions, during winter, when flow rates are high and salinities and temperatures are low, dissolution rates will probably be low also. Conversely, during summer and early fall when salinities are highest in the lower reaches of the estuary, dissolution rates will probably be high. In the mesohaline regions of the estuary, the dramatic increase in dissolution rate between 10 and $20 \%$ may result in large changes in the rate of silicic acid dissolution with small changes in salinity. This region is also just downstream from the zone of highest diatom productivity (Anderson, 1982). Consequently, the highest rates of regeneration of silicic acid would be expected in the higher salinity portion of the estuary, during the warmest months, and just after the period of maximum diatom productivity.

Temporal and spatial availability of silicic acid in the water column must depend on the balance between its removal from the water column for biogenic silica formation and its resupply from fluvial sources and regeneration. D'Elia et al., (1983) have shown that silicic acid concentrations in the Chesapeake are lowest during the late spring, the period of highest demand by diatoms. Conversely, silicic acid concentrations are high during periods of high flow in the spring and also when regeneration rates are high in the late summer. Pilson et al. (1980) reported similar results for a marine microcosm located in Narragansett Bay, Rhode Island. Late summer allochthonous inputs of silicic acid into Chesapeake Bay are low, so that most of the silicic acid in the water column during this period must be from authochthonous sources.

Longitudinal transects of western shore tributaries of the Chesapeake Bay show typical summer profiles of silicic acid (Anderson, 1982; D'Elia et al., 1983). Incoming river water has high silicic acid concentrations. Typically, there is a bloom of phytoplankton in the tidal freshwater reaches just above the limit of salt intrusion. Silicic acid concentrations become depleted to very low levels coincident with the phytoplankton bloom, and do not recover until farther downstream. This pattern suggests that silicic acid is removed from the water column upstream and is resupplied farther downstream; this is consistent with our findings that regeneration rates of silicic acid are low at low salinities and increase in the higher salinities found in the downstream portions of the estuary. Thus, the salinity 'transition' zone of the estuary seems to repre- sent an important spatial gradient with respect to processes affecting silicon cycling in the estuary.

Our study also has implications relevant to the preservation of diatom frustules in sediments along the length of an estuary. Because of the differential solubilities of diatoms in fresh and salt water, diatoms are likely to be much better preserved in the lower salinity portions of the estuary than farther downstream. As a result, stratigraphic work that depends on comparisons of diatom frustules preserved in the sediments in different salinity portions of the estuary must be interpreted cautiously, especially when there are strong seasonal and interannual variations in prevailing salinities in the overlying water column.

Acknowledgements. We thank D. Nelson, W. Boynton, J. Means, G. Anderson and $K$. Webb for fruitful discussions during this work and $F$. Younger for doing the figures. This research was supported by the Maryland Sea Grant Program.

\section{LITERATURE CITERD}

Aller, R. C., Benninger, L. K. (1981). Spatial and temporal patterns of dissolved ammonium, manganese, and silica fluxes from bottom sediments of Long Island Sound, U.S.A. J. mar Res. 39: 295-314

Anderson, G. F. (1982). The distribution of dissolved silica and particulate biogenic silica in the James, York, and Rappahannock estuaries, Virginia. Master's thesis, Virginia Institute of Marine Science, College of William and Mary, Virginia

Bennekom, A. J. van, Krijgsman-van Hartingsveld, E., van der Veer, G. C. M, van Voorst, H. F. J. (1974). The seasonal cycles of reactive silicate and suspended diatoms in the Dutch Wadden Sea. Neth. J. Sea Res. 8: 174-207

D'Elia, C. F., Nelson, D. M., Boynton, W. R. (1983) Chesapeake Bay nutrient and plankton dynamics: III. The annual cycle of dissolved silicon. Geochim. cosmochim. Acta 47: 1945-1955

Greenberg, S. A., Price, E. W. (1957). The solubility of silica in solutions of electrolytes. J. Phys. Chem. 61: 1539-1541

Guillard, R. R. L., Ryther, J. H. (1962). Studies of marine planktonic diatoms. I. Cyclotella nana Hustedt, and Detonula confervacea (Cleve) Gran. Can. J. Microbiol. 8: 229-239

Helder, W., de Vries, R. T. P., Rutgers van der Loeff, M. M. (1983). Behavior of nitrogen nutrients and dissolved silica in the Ems-Dollard Estuary. Can. J. Fish. aquat. Sci. 40 (Suppl. 1): 188-200

Hurd, D. C. (1972). Factors affecting solution rate of biogenic opal in seawater. Earth Planet. Sci. Lett. 15: 411-417

Hurd, D. C. (1973). Interactions of biogenic opal, sediment and seawater in the Central Equatorial Pacific. Geochim. cosmochim. Acta 37: 2257-2282

Hurd, D. C., Theyer, F. (1975). Changes in the physical and chemical properties of biogenic silica from the Central Equatorial Pacific. I. Solubility, specific surface area, and solution rate constants of acid-cleaned samples. In: Gibbs, T. R. P. Jr. (ed.) Analytical methods in oceanography. Advances in Chemistry Series No, 147. Am. Chem. Soc. $211-230$ 
Kamatani, A. (1971). Physical and chemical characteristics of biogenous silica. Mar. Biol. 8: 89-95

Kamatani, A., Riley, J. P. (1979). Rate of dissolution of diatom silica walls in seawater. Mar. Biol. 55: 29-35

Kato, K., Kitano, Y (1968). Solubility and dissolution rate of amorphous silica in distilled and sea water at $20^{\circ} \mathrm{C}$. J. oceanogr. Soc. Japan 24: 147-152

Lawson, D. S., Hurd, D. C., Pankratz, H. S. (1978). Silica dissolution rates of decomposing phytoplankton assemblages at various temperatures. Am. J. Sci. 278: 1373-1393

Lewin, J. C. (1961). The dissolution of silica from diatom walls. Geochim. cosmochim. Acta 21: 182-198

Lyman, J., Fleming, R. H. (1940). Composition of sea water. J. mar. Res. 3: 134-146

Matisoff, G., Bricker, O. P. III, Holden, G. R. Jr., Kaerk, P. (1975). Spatial and temporal variations in the interstitial water chemistry of Chesapeake Bay sediments. In: T. M. Church (ed.) Marine chemistry in the coastal environment. Am. Chem. Soc. Symp. Series 18: 343-363

Nixon, S. W. (1981). Remineralization and nutrient cycling in coastal marine ecosystem. In: Neilson, B. J., Cronin, L. E. (ed.) Estuaries and nutrients. Humana Press, Inc., Clifton, N. J., p. 111-138
Paasche, E. (1973). Silicon and the ecology of marine plankton diatoms. I. Thalassiosira pseudonana (Cyclotella nana) grown in a chemostat with silicate as limiting nutrient. Mar. Biol. 19: 117-126

Pilson, M. E. Q., Oviatt, C. A., Nixon, S. W (1980). Annual nutrient cycles in a marine microcosm. In: Geisy, J. P. Jr. (ed.) Microcosms in ecological research, U. S. Technical Information Center, U.S. Department of Energy, Symposium Series 52 (CONF-781101), p. 753-778

Taft, J. L., Taylor, W. R., Hartwig, E. O., Loftus, R. (1980). Seasonal oxygen depletion in Chesapeake Bay. Estuaries 3: 242-247

Van Valkenburg, S. D., Jones, J. K., Heinle, D. R. (1978). A comparison by size class and volume of detritus versus phytoplankton in Chesapeake Bay. Estuar. coast. mar. Sci. 6: 569-582

Werner, D. (1977). Silicate metabolism. In: Werner, D. (ed.) The biology of diatoms. Botanical monographs, Vol. 13. University of California Press, Berkeley and Los Angeles, p. $110-149$

Wilke, R. J., Dayal, R. (1982). The behavior of iron, manganese and silicon in the Peconic River estuary, New York. Estuar. coast. Shelf Sci. 15: 577-586

This paper was presented by Dr. J. H. Ryther; it was accepted for printing on March 13, 1984 